\title{
A Nature Tourism Route through GIS to Improve the Visibility of the Natural Resources of the Altar Volcano, Sangay National Park, Ecuador
}

\author{
Alex Vinicio Gavilanes Montoya ${ }^{1}$ (D) José Fernando Esparza Parra ${ }^{1}$, Carlos Renato Chávez Velásquez ${ }^{1}$ (D), \\ Paúl Eduardo Tito Guanuche 2,3, Grace Maribel Parra Vintimilla 4, Carlos Mestanza-Ramón 5,6,*(D) \\ and Danny Daniel Castillo Vizuete ${ }^{1, *(\mathbb{D}}$
}

Citation: Gavilanes Montoya, A.V.; Esparza Parra, J.F.; Chávez Velásquez, C.R.; Tito Guanuche, P.E.; Parra Vintimilla, G.M.; Mestanza-Ramón, C.; Castillo Vizuete, D.D. A Nature Tourism Route through GIS to Improve the Visibility of the Natural Resources of the Altar Volcano,

Sangay National Park, Ecuador. Land 2021, 10, 884.

https://doi.org/10.3390/

land 10080884

Academic Editors: María de la Cruz del Río-Rama,

José Álvarez-García,

Amador Durán-Sánchez and

Pedro Cuesta-Valiño

Received: 7 August 2021

Accepted: 20 August 2021

Published: 23 August 2021

Publisher's Note: MDPI stays neutral with regard to jurisdictional claims in published maps and institutional affiliations.

Copyright: (c) 2021 by the authors. Licensee MDPI, Basel, Switzerland. This article is an open access article distributed under the terms and conditions of the Creative Commons Attribution (CC BY) license (https:// creativecommons.org/licenses/by/ $4.0 /)$.
1 Faculty of Natural Resources, Escuela Superior Politécnica de Chimborazo (ESPOCH), Panamericana Sur km 1 $\frac{1}{2}$, Riobamba EC-060155, Ecuador; a_gavilanes@espoch.edu.ec (A.V.G.M.); jose.esparza@espoch.edu.ec (J.F.E.P.); renato.chavez@espoch.edu.ec (C.R.C.V.)

2 Ministerio de Ambiente, Agua y Transición Ecológica del Ecuador, Chile 10-51 y Darquea, Riobamba EC-060155, Ecuador; paul.tito@ambiente.gob.ec

3 Investigador Asociado-Instituto Nacional de Biodiversidad del Ecuador, Pje. Rumipamba N. 341 y Av. de los Shyris (Parque La Carolina), Quito EC-170150, Ecuador

4 Red Iberoamericana de Investigadores en Turismo y Territorio, Avenida 11 de noviembre y Canónigo Ramos, Riobamba EC-060155, Ecuador; gracemaribelparra@gmail.com

5 Departamento Economía Financiera y Dirección de Operaciones, Universidad de Sevilla, 41018 Sevilla, Spain

6 Instituto Superior Tecnológico Universitario Oriente, La Joya de los Sachas EC-220101, Ecuador

* Correspondence: carmesram@alum.us.es (C.M.-R.); danny.castillo@espoch.edu.ec (D.D.C.V.); Tel.: +593-968277770 (C.M.-R.); +593-987712497 (D.D.C.V.)

Abstract: Tourism in natural areas attracts people seeking contact with pristine ecosystems as opposed to a polluted urban habitat and a stressful pace of life. An adequate tourist route and itinerary guarantees a high level of tourist satisfaction. The objective of this study was to focus on the design of a tourist route and itinerary in the Altar Volcano, Sangay National Park, central Ecuador, by integrating tourist attractions and facilities. Within the methodological process, the main tourist attractions of the area were identified and georeferenced; then, a thematic map was elaborated using ArcGIS $10.5^{\circledR}$ software. Distances were determined by considering the transportation alternatives in relation to the base camps. Finally, the itinerary was structured by considering the possible tourist activities of each place or attraction. As a result, a tourist route was obtained that included 19 attractions and an itinerary that interacts with various activities in the study area. This research will strengthen tourism activities in the Altar Volcano, allowing for an increase in the number of visitors and the development of sustainable tourism thanks to proper planning in the use of a new tourist route.

Keywords: Sangay National Park; nature tourism; GIS design; sustainable development

\section{Introduction}

Tourism is currently one of the most important economic and cultural activities that a country or region can count on. Tourism activities may be implemented in many variants, one of them and one of the fastest growing in recent years being nature-based tourism. There is no doubt that tourism has contributed to the economic development through the generation of jobs, income, and improvement of countries' visibility [1,2]. However, this situation has changed due to the COVID-19 pandemic, which has caused huge losses in this sector; at the global level, it was estimated that there was a loss of 300 to 450 billion dollars in inbound tourism in 2020 [3]. The United Nations World Tourism Organization (UNWTO) indicated that the arrival of foreign tourists recorded a historic decline by sanitary crisis; the number of international tourists in May 2020 was reduced by $98 \%$ compared to 2019 [4]. The prospects for a tourism upturn in 2021 have not became a 
reality due to the increase in the number of contagions of COVID-19 in many countries; despite this trend, it has been suggested that tourism might be reactivated in the middle of 2021 or in 2022, as well as that the principal tourism activities might take place in nature [5]. In this context, for the development of tourist activity, biosecurity aspects for tourists must also be considered [6].

Nature-based tourism is mainly characterized by visits to natural landscapes, and its main associated activity is the observation of the surroundings $[7,8]$. This type of tourism involves the environment, its conservation, and culture, as well as economic and social aspects that generate benefits for locals [9]. Ecuador has an advantage over other competitors in this segment of tourism, being considered one of the 17 countries with the greatest biodiversity or biological wealth on the planet. The country holds important biomes and ecosystems such as dry and humid tropical forests, savannas, mountain forests, highlands, and mangroves. These are important aspects for tourists when choosing a nature destination, since they will allow them to have a greater probability of observing the fauna and flora representative of their ecosystems [10]. As such, in Ecuador, the main activities of interest for foreign tourists are cultural tourism $(58.9 \%)$, nature-based tourism $(20.8 \%)$, sun and beach tourism $(15.9 \%)$, adventure tourism $(3.2 \%)$, and other activities $(1.2 \%)$ [11]. Currently, domestic tourism has become important as it has allowed to boost the economy; in this context, a study carried out on the characteristics of the world's new situation suggested that destinations such as mountains $(12.01 \%)$, protected areas (PA) $(9.27 \%)$, rural $(5.07 \%)$, or urban $(6.87 \%)$ places are preferred by tourists and visitors [12].

The satisfaction of tourists can be defined like a reaction or decision that describes the tourist's thoughts and emotions regarding an experience in a tourist place [13], and it is directly related to the quality of tourism experiences [13-15] and the destination attributes [14]. In addition, the dimensions linked to the satisfaction level are the (i) destination (which is characterized by security, access, information, and signage), (ii) services (accommodation, transport, tour operators, and others), and (iii) infrastructure [16]. Therefore, it is important to hold a tourist product that contributes to the enjoyment of the tourist. It includes aspects of tourist offer such as tourist attractions, and services provided by the tourist infrastructure for other non-tourist goods. Thus, at a basic level, it is formed by facilities (accommodation, food, entertainment, travel agencies or operators) and accessibility (transport and routes), while the highest level or a complete experience is achieved thanks to tourist attractions [17]. In short, tourist satisfaction is important because it influences the choice of destination, the consumption of tourist goods and services, and the intention to return to the site. Thus, a tourist who has had excellent experience in recreational activities at a site will recommend that destination to more travelers, and studies have shown that sites are often visited by new tourists mainly on the recommendation of satisfied visitors [18].

A proper planning of tourist activity should guarantee the success of a destination. Consequently, an integrated design of the tourist product, which has to include a marketing plan, is required to achieve a competitive destination [19]. An integrated design of a tourist product is usually done in the following stages: (1) characterization of the demand, (2) design of the product that includes the (i) identification of tourist attractions or resources, (ii) generation of ideas, selection of activities, and conceptualization of the product, (iii) tourist product and integration of the offer, and (iv) evaluation by feasibility studies [20], and (3) positioning [21]. Tourism planning is fundamental to the development of recreational and adventure activities because it guarantees the correct integration of tourism into the economy, society, culture, and environment. It is important to emphasize that adequate management of tourism demand is indispensable for local economic dynamization and should be in line with current global trends [22].

The appearance of new products based on tourist routes or itineraries involves the application of strategies, such as specialization, diversification, complementation, and others [23], whose line of action must be based on tourist offer and demand and on tourist preferences $[23,24]$. Many authors consider that a tourist route is a tourist product or destination because it links a series of attractions to services [25-28]. For instance, Hernández 
(2011) [29] indicated that "like the guides that direct the visit in the cities, the routes aim to conduct the activities highlighting what is worth knowing about the tourist territory." Methodologies to design a tourist route are variable. In this context, the Ministry of Tourism from Ecuador [27] proposed the following steps to create a tourist route: (1) identification and classification of tourist attractions, (2) georeferencing and location of tourist places (infrastructure or attractions), (3) tourist distribution model, (4) tourist product (itinerary), (5) innovation (generation of complementary activities), and (6) commercialization and promotion. A tourist itinerary is the graphic expression of the direction to follow within a tourist route or product [27], and it contains detailed information about daily movements, date, transportation modality [30], tourist attractions, duration (time), and activities, including services [27-31].

The province of Chimborazo and its protected areas are characterized by their richness in terms of natural resources; their ecosystem components make up mountain landscapes with a high potential for nature-based tourism [32,33]. Historically, one of the most popular mountain sites for tourism in the province and the country has been the Chimborazo Volcano [34]. However, this trend in the province is changing [35], so that in recent years, increasingly popular are the trips to the Altar Volcano (AV), which is located in the Sangay National Park (SNP) and which became famous for its resources such as the lakes, peaks, and the long trekking to climb it.

Considering this new trend of mountain nature tourism and an increasing influx of tourists, current problems have been evidenced such as the current time required to cover the route from the start to the top of the mountain, its difficulty, restriction of access to the mountain to only highly trained hikers and climbers, and last but not least, the absence of many natural features in the existing route, which could be a factor that decreases the interest of nature-based tourists [36]. Thus, the objective of this study focused on designing a new nature tourism route in the Altar Volcano in the SNP that would serve as a sustainable management tool for managers and authorities in the province of Chimborazo, Ecuador. A mixed exploratory and descriptive methodology was used. The field work, together with the bibliographic review, made it possible to inventory the sites of interest and the available activities. Finally, the information was processed with the support of ArcGIS $10.5^{\circledR}$ software, allowing the construction and description of a new nature tourism route and its itinerary.

\section{Materials and Methods}

\subsection{Study Area}

The Altar Volcano has an altitude of 5319 m.a.s.l., which makes it the fifth highest mountain in Ecuador. It is located between the provinces of Morona Santiago and Chimborazo in the south-central eastern Andean region of Ecuador (Figure 1), in the Sangay National Park, which is one of the 62 protected areas of the country. The main access to the Altar Volcano is through the rural parish of Quimiag, which is located in the Riobamba Canton. The volcano is characterized by its inactivity, being covered by glaciers, and exhibiting several peaks as a result of its past activities. Its name-Altar-comes from its resemblance of the altar of a church; in addition, its summits have very special ecclesiastical names, such as "Bishop". It is considered one of the most representative mountains in the country, thanks to its scenic beauty. The presence of lakes between its glaciers and peaks makes this volcano a resource with high tourist potential, thanks to its unique panoramic views. 


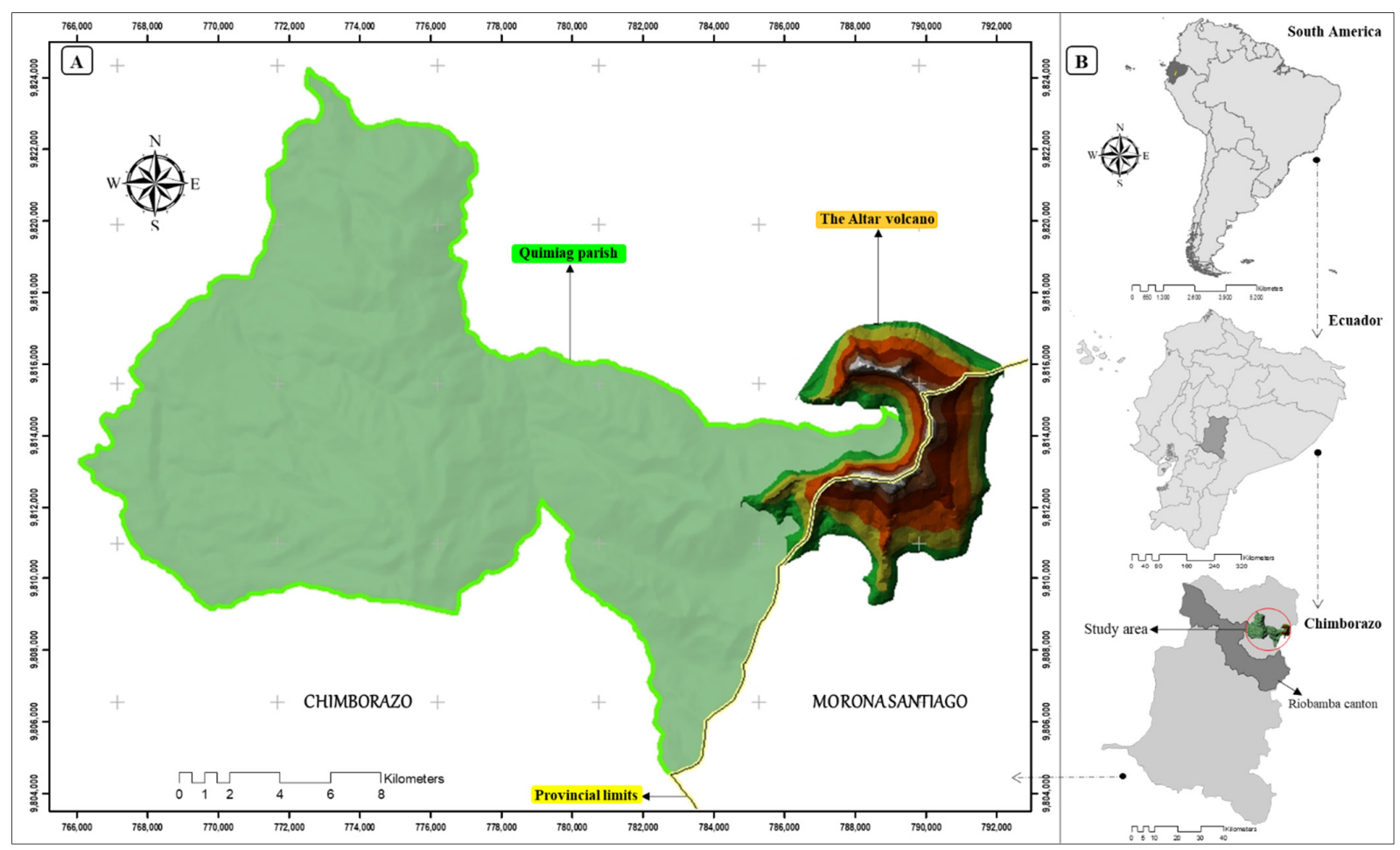

Figure 1. Map of the study area. (A) Altar Volcano location; (B) location in relation to Altar Volcano in South America, Ecuador, Chimborazo Province, and Riobamba Canton.

\subsection{Methodology}

The methodology used in this study was explorative, analytical, and descriptive (Figure 2). For a better understanding, the methodological process, which responds to the objectives set out in this study, has been sectioned. In the first section, through the use of literature review and field exploration, a mapping (georeferencing and description) of the main points of tourist interest in the study area was carried out. Secondly, by using ArcGIS $10.5^{\circledR}$ and Google Earth Pro, the information was analyzed to create the route and the itinerary, considering the tourist attractions, their distances, potential activities, and travel time.

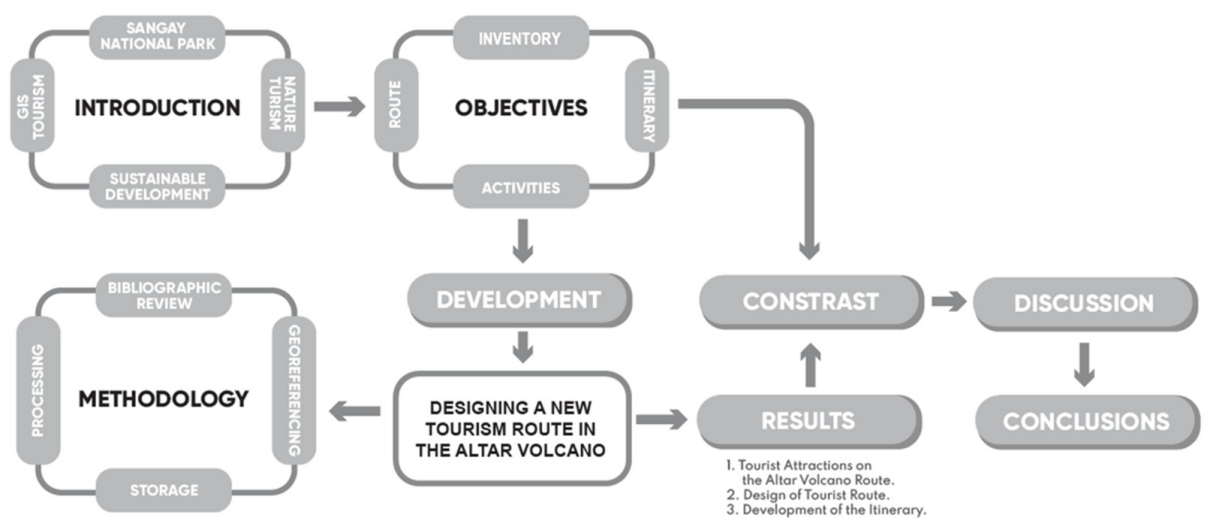

Figure 2. Methodological research process.

\subsubsection{Mapping of the Main Points of Tourist Interest}

The processes of mapping and describing the main points of tourist interest are described in Table 1. First, a bibliographic review was carried out, which allowed to identify the main points of tourist interest and facilities in the study area. In this first process, 
scientific literature such as articles and books indexed in regional databases (Scielo and Redalyc) and high-impact databases (Scopus and Web of Science) were reviewed. Information complemented with gray literature such as reports and tourist guides, provided by governmental institutions such as the Ministry of Tourism and Decentralized Autonomous Governments. Afterwards, an initial database was designed with the tourist attractions and their geolocations marked on the route obtained through a field trip. For this purpose, the tourist attractions were georeferenced in the field using a GPS (Global Positioning System) unit (model: GPSMAP ${ }^{\circledR}$ 66i; make: GARMIN; city: Kansas; country: United States of America) technology and mobile applications such as "C7 GPS Datos," "All Trails," "Maps.me," and "UTM Geo Map," while the rest of the points were identified and georeferenced using desktop software such as Google Earth.

Table 1. Methodological steps used to collect data for the points of interest.

\begin{tabular}{ccc}
\hline Collection Technique & Description & Results \\
\hline Bibliographic review & Identification of points of interest & Knowledge \\
\hline Georeferencing & Visit and tourist route in AV & $\begin{array}{c}\text { Coordinates and information of } \\
\text { points of interest }\end{array}$ \\
Storage & $\begin{array}{c}\text { The information collected from } \\
\text { points of interest by different } \\
\text { teams was merged into a database }\end{array}$ & Coordinates, altitude, and photos \\
\hline Processing & $\begin{array}{c}\text { The information was processed in } \\
\text { ArcGis 10.5 to locate the points } \\
\text { within different maps }\end{array}$ & Georeferenced points \\
\hline
\end{tabular}

During this phase, the guidance of experienced local people was important to suggest the most visited and accessible attractions. Finally, the collected information (coordinates) was processed in ArcGIS $10.5^{\circledR}$ software using the Universal Transverse Mercator Reference System (UTM), World Geodetic System (WGS 1984), zone 17. This information was crosschecked and validated with official tourism information provided by the local government of Riobamba [37-39].

\subsubsection{Tourist Route Design}

Once the identification of the tourist attractions was made through bibliographic review and validated with field work, the interest points and tourist features were shortly described, coded, and located according to the province to which they belonged. For a better description and analysis, the route included two alternatives, resulting in a network of attractions interconnected by possible routes. The first alternative was proposed for trekking, while the second was planned for climbers to reach the summit of the mountain. Both alternatives were planned for a two-day itinerary.

For the design of the tourist route, the input files were the layers (images) obtained from the official international satellite image download portals, which were projected to the Universal Transversal Mercator (UTM), World Geodetic System (1984), zone 17 S coordinate system, considering that these geographic features are specific for the Continental Ecuador, in central Highland Region [40-42]. The starting and finishing points of the route were identified, and for the design of the route, maps of the study area and georeferenced tourist attractions and facilities were used. To this end, georeferencing tools of ArcGIS 10.5 software and Google Earth Pro allowed to integrate the network of attractions.

The distances traveled between tourist attractions were calculated based on a field trip done on 28 and 29 December 2020 with the participation of native people and of the research team of the Escuela Superior Politécnica de Chimborazo (ESPOCH). From the viewpoints, reference distances were calculated in a straight line to observe specific attractions. The field calculator tool of ArcGIS $10.5^{\circledR}$ software was used for this purpose.

Once the information has been reviewed, explored, and analyzed, the results are presented. The first section describes the mapping of the main sites of tourist interest in 
the Altar Volcano area of SNP. Additionally, the design of the tourist route and its itinerary were described. In this section were include some flora and fauna species which were obtained through rapid biological inventories along the route.

\section{Results}

\subsection{Tourist Attractions on the Altar Volcano Route}

Nineteen points of tourist interest were identified through the field trips. The interest points in the area (Table 2) are represented by tourist attractions and tourist facilities (base camps). To this end, "Vasija" (VJ), located in Riobamba city, was considered the starting point of reference in the road network toward the AV. Each tourist attraction was mapped and represented by a point and labeled with a red number as shown in Figures 2 and 3.

The mountain lake complex "El Altar" corresponds to periglacial wetland formations, whose height varies from 3803 to 4553 m.a.s.l.

\subsection{Design of Tourist Route}

Once the mapping and description of the main tourist sites in the study area was completed, the 19 tourist points were grouped into two alternatives (Figure 3). In addition, the reference distance to the attractions in a straight line was included, with respect to the observer. For instance, from point 14, it is possible to observe tourist attractions at points 15 , and 16 . However, the distances indicated in a straight line are not practicable by trekking. They are only representing the distance to a point of interest that can be viewed from a given point on the route

The main route including alternative 1 corresponds to the trekking route; this zone is characterized by ecosystems with abundant Andean vegetation and minimal anthropogenic impacts in terms of land use changes. Alternative 2 represents the mountain climbing alternative to the summit of the $\mathrm{BP}$, which is the highest peak of the AV. Moreover, on the route it is possible to observe landscapes of mountain tourism such as the peaks and the lake system. It should be noted that alternative 2 should be covered only with organized groups and tour operators regulated in the information system which should have guides specialized in mountain adventure.

Figure 4 and Table 3 show the distances between the different tourist attractions, which make the route (BT PG, BC, GA, VV, ML, MC, PL, CAV, and IC) by taking into consideration the possible ways of traveling or viewing between any two given points. Therefore, the distances between any two given points for which a ground transportation possibility is specified represent the real ground distances, while the distances between any two given points for which "only viewing" is specified as an alternative represent the straight-line reference distance between those points extracted from the used mapping software. These lines were considered just to see the attractions because there are no established routes. In addition, the topographic conditions of the terrain are not optimal to visit the attractions.

The total distance of the general route is $45.14 \mathrm{~km}$, which starts from the VJ point and ends at the MC point. The trekking route includes the general route and the first alternative, which make a total distance of $46.51 \mathrm{~km}$, up to the CAV point (point 14, Figures 2 and 3). Finally, the planned alternative for climbers to reach the summit of AV has a distance of $47.98 \mathrm{~km}$.

The longest distance to travel is from VJ to BT $(33.26 \mathrm{~km})$, which corresponds to a travel by vehicle. For the trekking route (alternative 1), a route is made from the BT to the MC, where tourist attractions such as the following are located: (i) the Padguazo forest (PG), (ii) the gates of the Altar viewpoint (GA) from where the lakes can be observed (SL, SIL, and GL), (iii) the viewpoint of the valley (VV), and (iv) the Mandur lake, to finally reach the Mandur camp (MC). From the second route which can be used to climb to the top of the AV from the viewpoint of the valley (VV), it is possible to observe the blue lake (BL) and walk towards the Italian camp (IC) prior to the ascent to Bishop peak (BP). 
Table 2. Interest points for tourists and their attributes in the study area.

\begin{tabular}{|c|c|c|c|c|}
\hline $\mathbf{N}^{\circ}$ & Points of Interest & Description & Code & Photography \\
\hline $\begin{array}{l}\text { Reference point of } \\
\text { departure }\end{array}$ & $\begin{array}{c}\text { Vasija } \\
\text { Roundabout }\end{array}$ & $\begin{array}{l}\text { Place of departure from } \\
\text { Riobamba city } \\
\text { (roundabout). }\end{array}$ & VJ & \\
\hline 1 & Bocatoma & $\begin{array}{l}\text { Located in the Inguisay } \\
\text { community. In this place } \\
\text { exists a hydroelectric } \\
\text { plant, where vehicle route } \\
\text { ends and walking tour } \\
\text { starts. }\end{array}$ & BT & \\
\hline
\end{tabular}

2

Padguazo
Plain located under the gates of Altar, which is used for camping for groups of more than 5 people.
Remnants of a Polylepis forest (Polylepis incana). It is a place to rest and camp.
PG

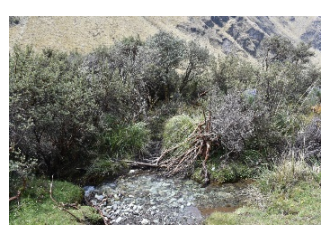

BC

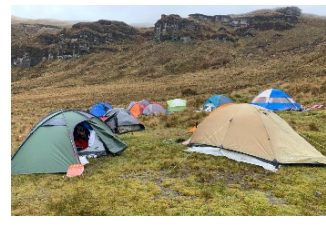

Camping site for small groups (2 to 4 people), safety point in case of severe weather changes.
MAC

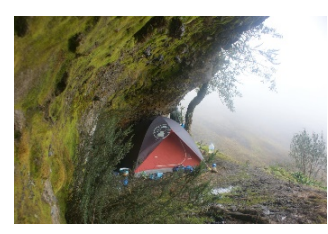

The entrance to the eastern mountain range, where the AV route starts It is a viewpoint and it is considered a reference for the limit of the SNP.

Star-shaped lake, located under the Panecillo hill. Water surface: 8.96 ha.

Altitude: 4092 m.a.s.l.

The first lake that is observed in the route. Water surface: 5.25 ha. Altitude: 4084 m.a.s.l. lake where the source of the Palora river begins, greenish in color. Water surface: 59.26 ha. Altitude:

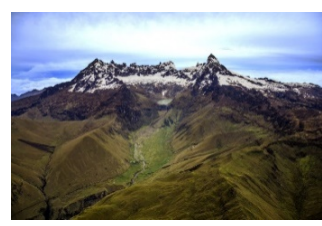
3803 m.a.s.l.
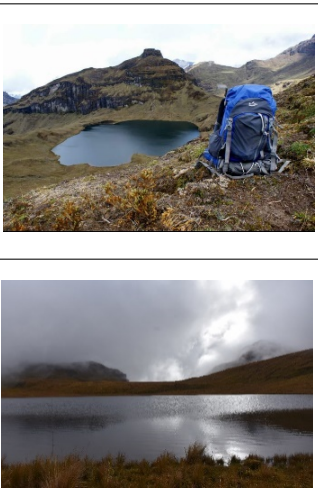

SIL

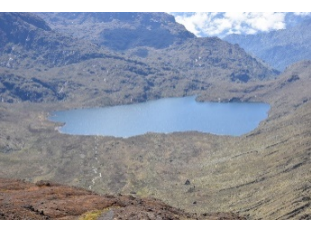


Table 2. Cont.

\begin{tabular}{|c|c|c|c|c|}
\hline $\mathbf{N}^{\circ}$ & Points of Interest & Description & Code & Photography \\
\hline 9 & $\begin{array}{c}\text { Valley } \\
\text { viewpoint }\end{array}$ & $\begin{array}{l}\text { Viewpoint from where it is } \\
\text { possible to see the lakes, } \\
\text { the valley, and the Altar } \\
\text { Volcano. From here one } \\
\text { can select the route to } \\
\text { Mandur and high } \\
\text { mountains, or the route to } \\
\text { the blue lake. }\end{array}$ & VV & \\
\hline 10 & Mandur lake & $\begin{array}{l}\text { Lake formed by the thaws } \\
\text { of the south face of the } \\
\text { volcano. It is part of the } \\
\text { upper basin of the Blanco } \\
\text { river. Water surface: } 5.48 \\
\text { ha. Altitude: } 4397 \text { m.a.s.l. }\end{array}$ & ML & \\
\hline 11 & $\begin{array}{c}\text { Mandur } \\
\text { waterfall * }\end{array}$ & $\begin{array}{l}\text { It is born from the glaciers } \\
\text { on the south face, a } \\
\text { product of the } \\
\text { accumulation of water } \\
\text { from Mandur Lake. It is a } \\
\text { waterfall of approximately } \\
300 \mathrm{~m} \text {. It can be seen } \\
\text { mainly from the base } \\
\text { camp. }\end{array}$ & MW & \\
\hline
\end{tabular}

ALTERNATIVE 1

Camp to complement the route.

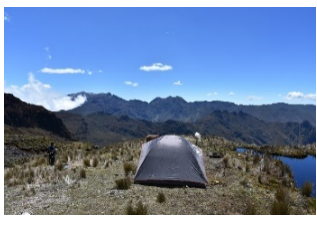

Located at the base of the Canaleta viewpoint. It is the highest lake in the lake complex. Water surface:

1.76 ha. Altitude: 4553

$$
\text { m.a.s.l. }
$$

It has the shape of a U-shaped opening in the structure of the volcano that allows to see the Collanes Valley and the crater of the Altar Volcano where the yellow lake is located.

It is a plain that is located below the yellow lake.

This attraction can be seen

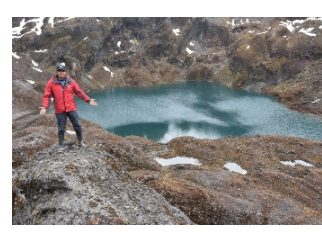

MC

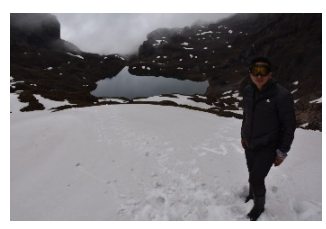
from the Canaleta viewpoint.

CAV

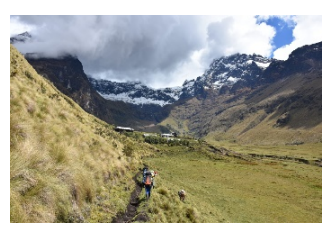

It is the main attraction of the Releche-El Altar Volcano route, which can be viewed from the Canaleta viewpoint. Water surface: 40.29 ha. Altitude: 4361 m.a.s.l.

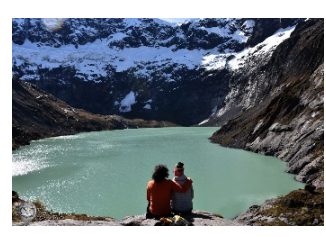


Table 2. Cont.

\begin{tabular}{|c|c|c|c|c|}
\hline $\mathbf{N}^{\circ}$ & Points of Interest & Description & Code & Photography \\
\hline \multicolumn{5}{|c|}{ ALTERNATIVE 2} \\
\hline 17 & Blue lake * & $\begin{array}{l}\text { It is the main attraction of } \\
\text { this route option apart } \\
\text { from the volcano due to its } \\
\text { scenic beauty. It is a } \\
\text { periglacial wetland that is } \\
\text { born from the thaws of the } \\
\text { Altar Volcano. Water } \\
\text { surface: } 51.15 \text { ha. Altitude: } \\
4223 \text { m.a.s.l. }\end{array}$ & $\mathrm{BL}$ & \\
\hline 18 & Italian Camp & $\begin{array}{l}\text { It is the main camp for the } \\
\text { high mountain route } \\
\text { whose main destination is } \\
\text { the summit of "El Obispo," } \\
\text { among others. }\end{array}$ & IC & \\
\hline 19 & Bishop peak & $\begin{array}{l}\text { It is the highest peak of } \\
\text { the El Altar Volcano with } \\
5319 \text { m.a.s.l., and it is } \\
\text { considered one of the most } \\
\text { difficult peaks in Ecuador. } \\
\text { A very high technical level } \\
\text { is required to access this } \\
\text { attraction. It is the highest } \\
\text { point of the SNP. }\end{array}$ & $\mathrm{BP}$ & \\
\hline
\end{tabular}

* Places that cannot be visited directly from the route but which can be seen from viewpoints or camps. 


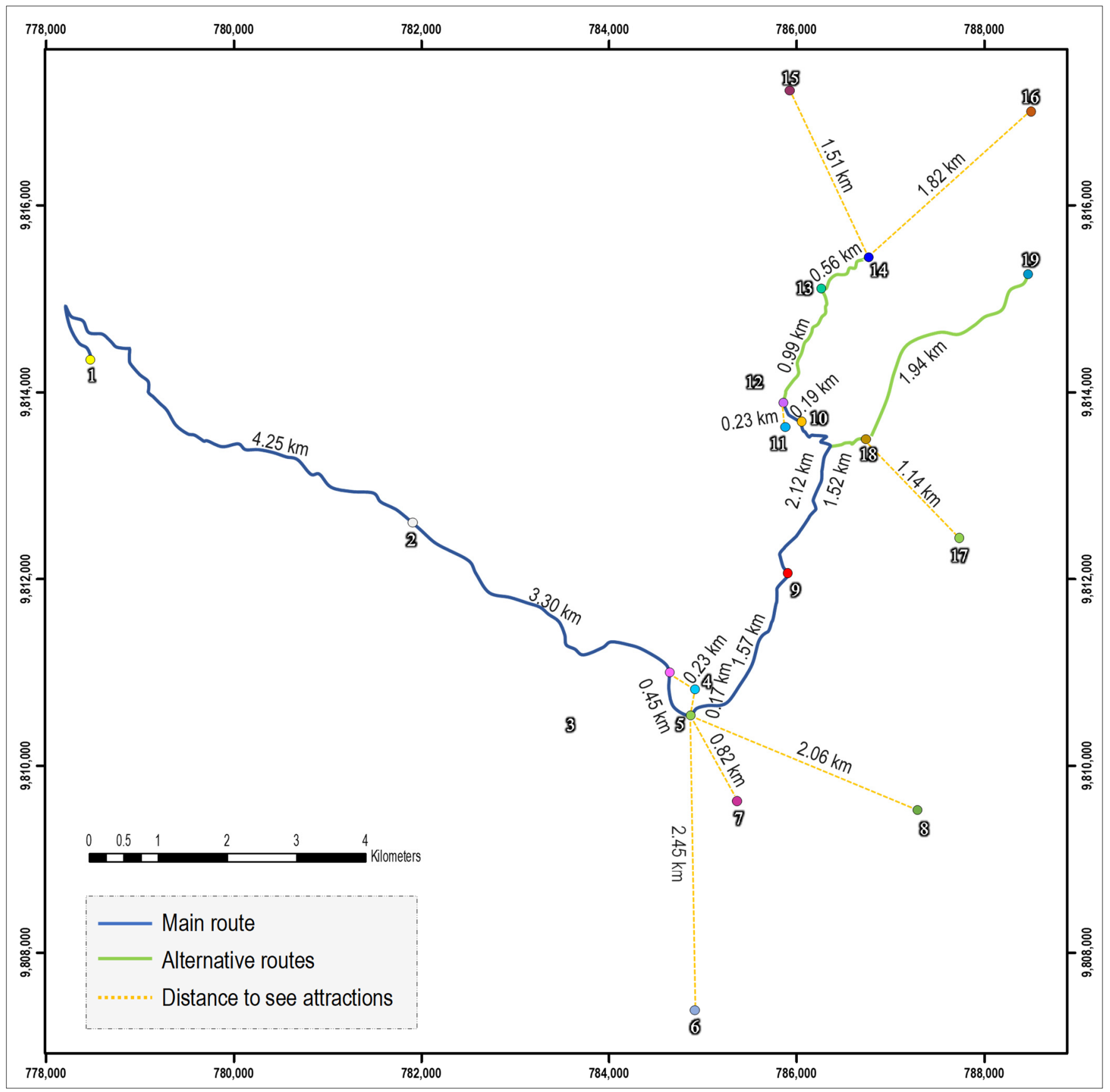

Figure 3. Network of tourist attractions identified by numbers in the study area. Legend: The study area is divided into the main route in blue color (numbers from 1 to 11); alternative 1 for trekking: points 12-16; and alternative 2 for high mountain route: points $17-19$. 


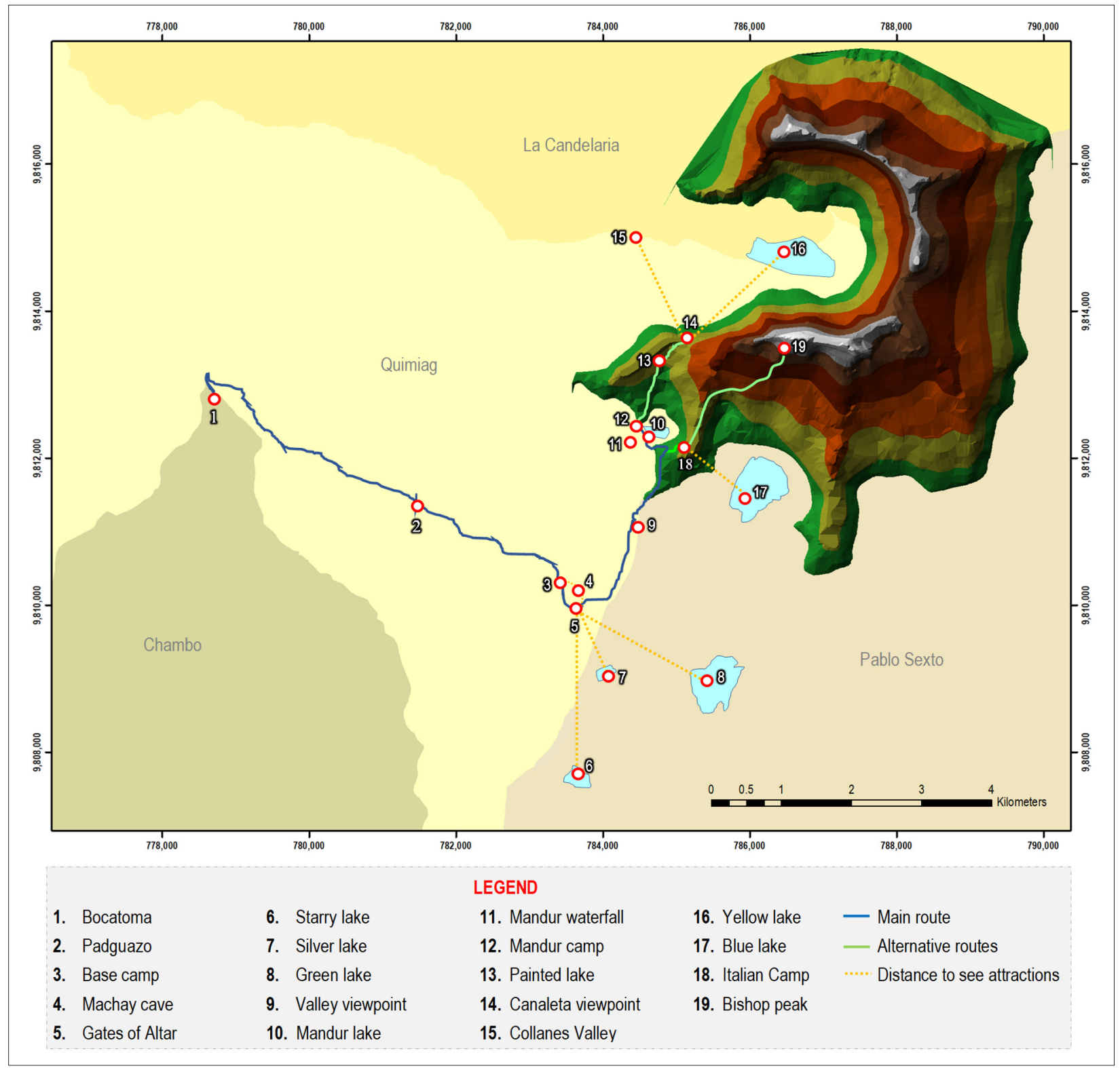

Figure 4. Tourist route on the Altar Volcano, Sangay National Park. 
Table 3. General description of distances routes in AV.

\begin{tabular}{|c|c|c|c|}
\hline Start Place & Arrival Place & $\begin{array}{c}\text { Distance between Points of } \\
\text { Interest }(\mathbf{k m})\end{array}$ & $\begin{array}{l}\text { Reference Distance to } \\
\text { Attractions (km) }\end{array}$ \\
\hline $\begin{array}{c}\text { Vasija (Reference point of } \\
\text { Departure) }\end{array}$ & Bocatoma & 33.26 & - \\
\hline Bocatoma & Padguazo & 4.25 & - \\
\hline Padguazo & Base camp & 3.30 & - \\
\hline Base camp viewpoint & Machay cave & - & 0.23 \\
\hline Base camp & Gates of Altar & 0.45 & - \\
\hline Gates of Altar viewpoint & Machay cave & - & 0.17 \\
\hline Gates of Altar & Valley viewpoint & 1.57 & - \\
\hline Gates of Altar viewpoint & Starry lake sighting & - & 2.45 \\
\hline Gates of Altar viewpoint & Silver lake sighting & - & 0.82 \\
\hline Gates of Altar viewpoint & Green lake sighting & - & 2.06 \\
\hline Valley viewpoint & Mandur lake & 2.12 & - \\
\hline Mandur lake & Mandur camp & 0.19 & - \\
\hline \multirow[t]{2}{*}{ Mandur camp } & Waterfall Mandur sighting & - & 0.23 \\
\hline & & ALTERNATIVE 1 & \\
\hline Mandur camp & Painted lake & 0.99 & - \\
\hline Painted lake & Canaleta viewpoint & 0.56 & - \\
\hline Canaleta viewpoint & Collanes valley sighting & - & 1.51 \\
\hline \multirow[t]{2}{*}{ Canaleta viewpoint } & Yellow lake sighting & - & 1.82 \\
\hline & & ALTERNATIVE 2 & \\
\hline Valley viewpoint & Italian camp & 1.52 & - \\
\hline Italian camp viewpoint & Blue lake & - & 1.14 \\
\hline Italian camp viewpoint & Bishop peak & 1.94 & - \\
\hline
\end{tabular}

\subsection{Development of the Itinerary}

Figure 5 and Figure 8 shows the general information of the tourist route considering relevant technical data of the journey. The information presented differentiates the routes from the general route with the alternative that is selected (trekking or ascent to the AV summit). Each option requires different levels of preparation, due to physical, technical, and equipment conditions. The route begins in Riobamba, for which it is recommended to have the proper equipment, clothing, and food, depending on the route to be taken (trekking and high mountains). For any option, the support of a certified local or national guide is necessary. In addition, along the way, there are wooden signs placed by the Ministry of Environment that refer to the SNP. 


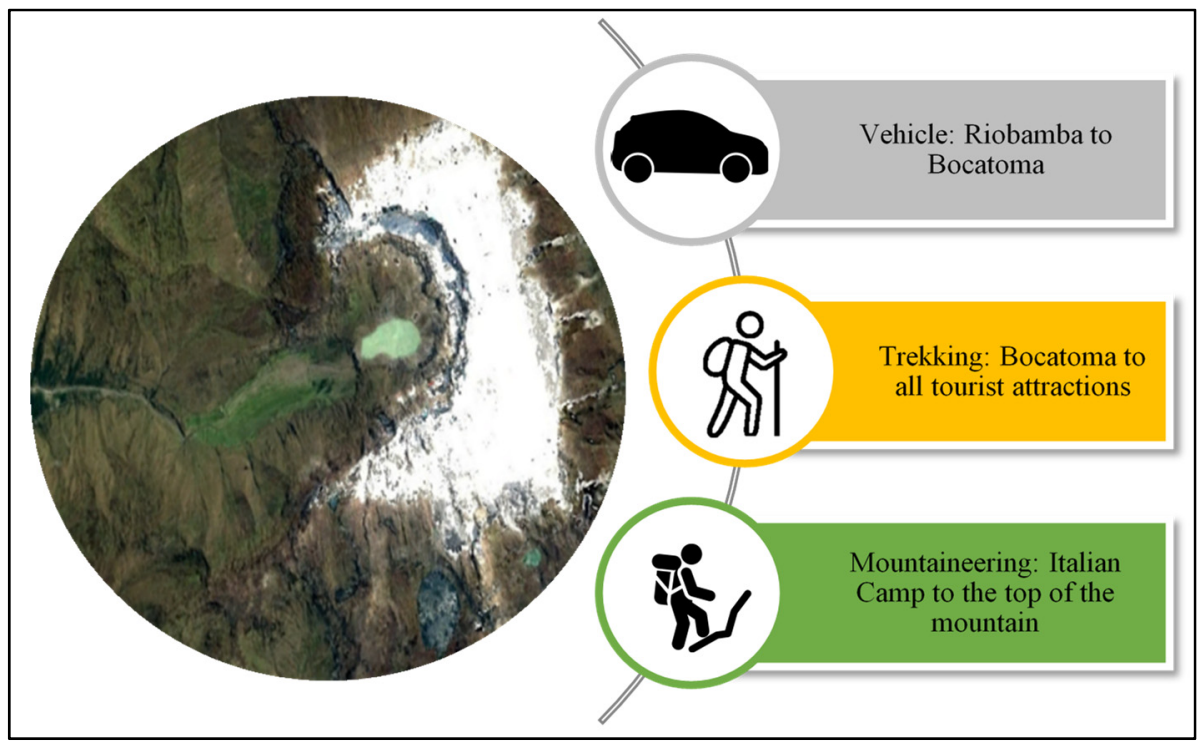

Figure 5. General information of the route.

Figures 6 and 7 show tourist attractions as AV and BL, in addition to the most representative flora and fauna species, respectively.

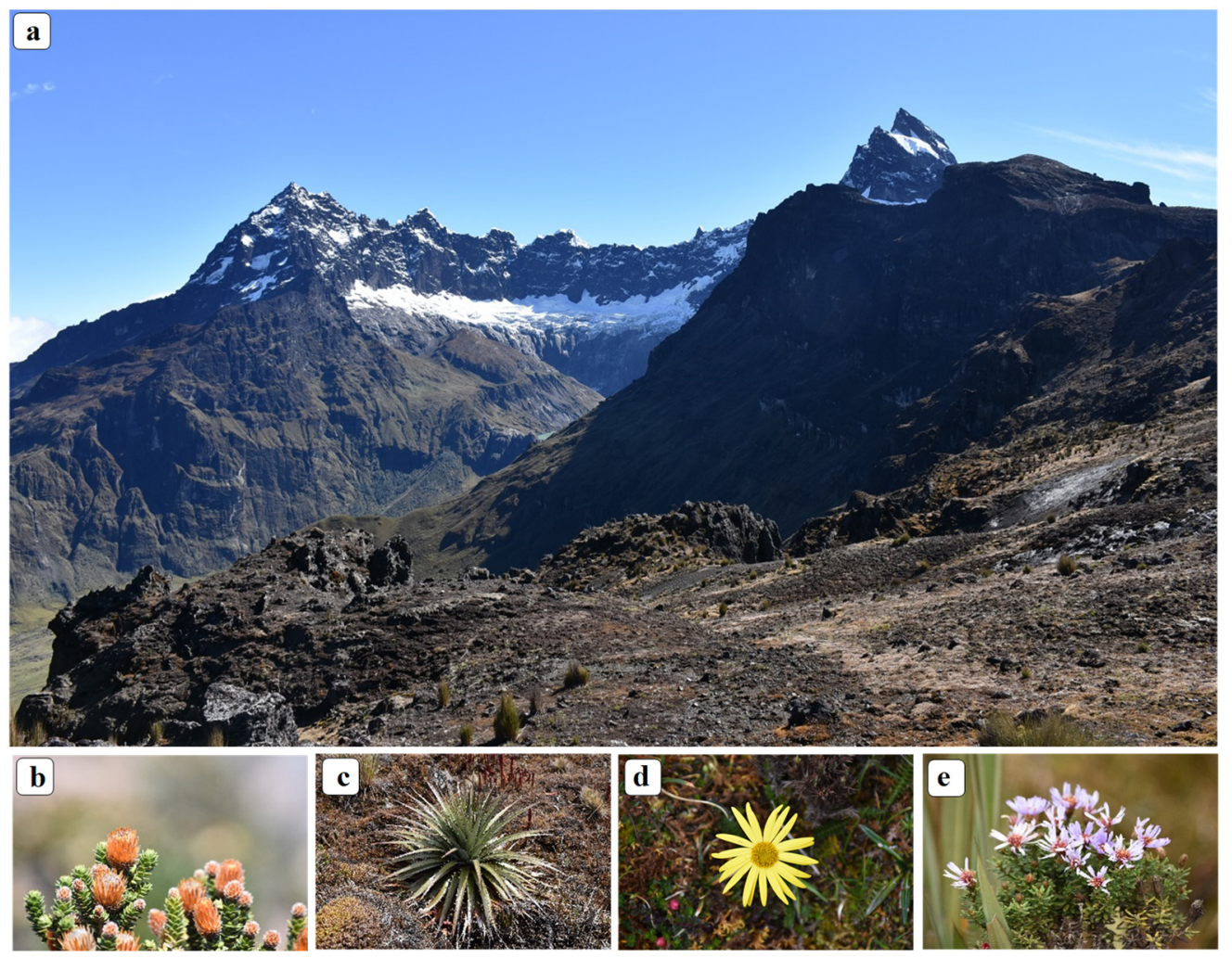

Figure 6. (a) Altar Volcano, (b) Chuquiraga jussieui, (c) Puya hamata, (d) Dorobaea pimpinellifolia, and (e) Silene acaulis. 


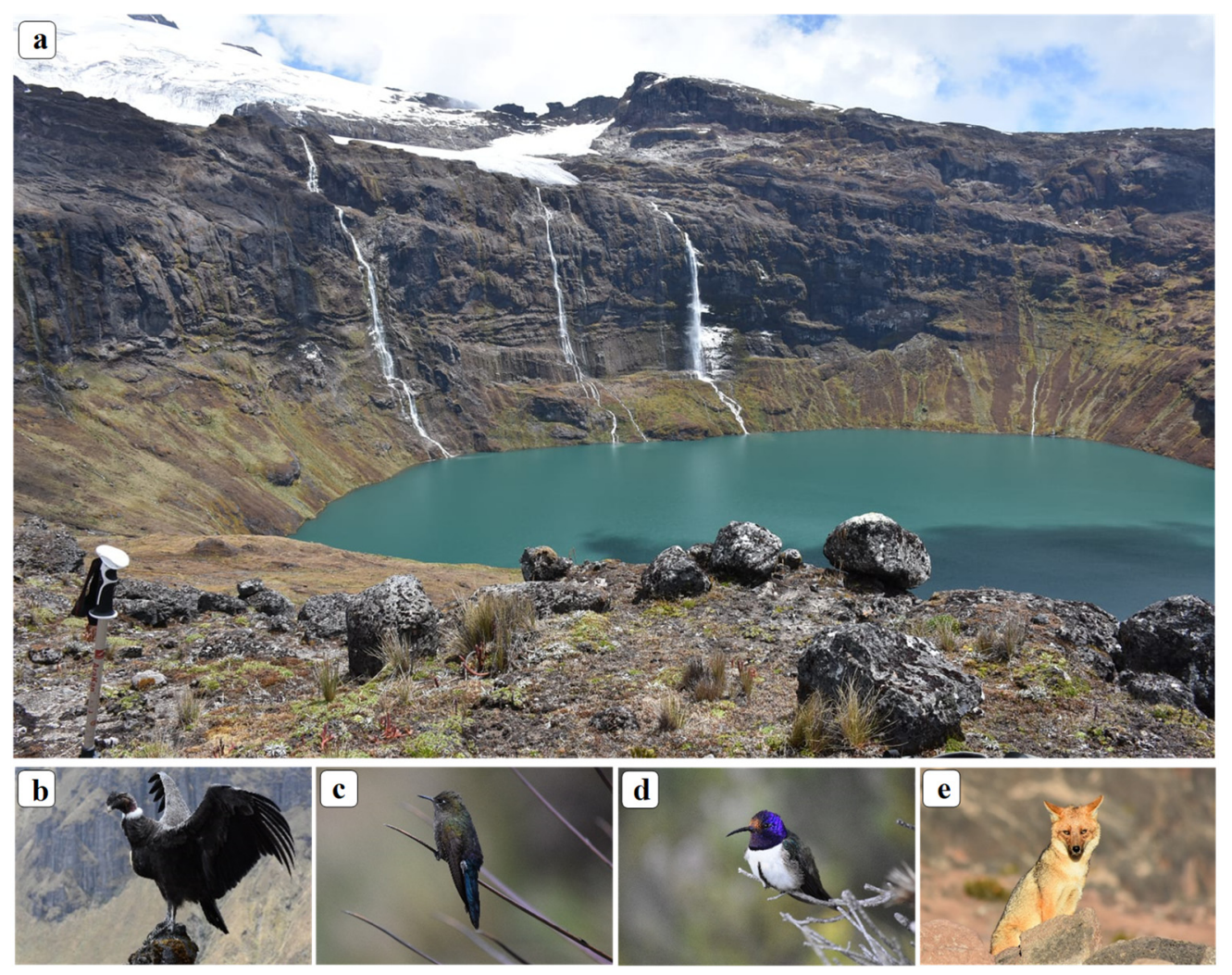

Figure 7. (a) Blue lake, (b) Vultur gryphus (male), (c) Chalcostigma stanleyi (female), (d) Oreotrochilus chimborazo (male), and (e) Lycalopex culpaeus.

Along the route, seven land use types and ecosystems can be observed, namely (i) managed land, (ii) high montane evergreen forest in the north of the Andes Mountain range (Inguisay community), (iii) highland evergreen forest (path before the forest), (iv) highland grassland (mostly), (v) highland sub-nival grassland and shrubland, (vi) water (wetlands, rivers, and lakes) and (vii) other areas such as rocky areas, rocky areas covered by snow, and glaciers.

Figure 8 describes the itinerary for trekking route or to climb to the AV. It was developed in two days considering that most of the locals and tourists frequent this route at that time.

By choosing the second alternative, it is possible to climb on the summit of "El Altar" (BP), but the trekking is very demanding and extremely technical, being suitable only for expert climbers. The peaks bear ecclesiastical names such as Bishop, Big Nun, Little Nun, Tabernacle, Eastern Friar, Blessed Friar, Central Friar, Big Friar, and Canon. This itinerary may enable various activities such as climbing, camping, photography, environmental interpretation, research, observation of flora and fauna, and trekking. Tourist facilities are trails, signs, sanitary batteries, food sales, and camping areas. Among the recommended equipment are insulation (foam mat), hiking sticks, a blocker, rubber boots, a medicine cabinet, a compass or GPS, wool socks, a tent, glasses, a wool cap, light gloves, a flashlight, a backpack of 35 to $45 \mathrm{~L}$ maximum capacity, warm and waterproof clothing, and a sleeping bag. 
Alternative 1: Visit to Canaleta

\begin{tabular}{|c|c|}
\hline \multicolumn{2}{|c|}{ DAY 1} \\
\hline Time & Activities description \\
\hline $06 \mathrm{~h} 00$ & Departure from Riobamba (Vasija roundabout) \\
\hline $07 \mathbf{h} 30$ & Arrival at the Bocatoma \\
\hline $08 \mathrm{~h} 00$ & Start of the route \\
\hline $09 h 30$ & Padguazo forest arrival and breakfast \\
\hline $10 \mathrm{~h} 00$ & Departure to base camp \\
\hline $11 \mathrm{~h} 30$ & Arrival to base camp and rest \\
\hline $12 \mathrm{~h} 00$ & Arrival at the gates of the Altar \\
\hline $13 \mathrm{~h} 00$ & Arrival at Valley viewpoint \\
\hline $15 \mathrm{~h} 00$ & Arrival at the Mandur Lake \\
\hline $15 \mathrm{~h} 15$ & Set up a tent at the Mandur camp and lunch \\
\hline $15 h 45$ & Departure to Painted lake \\
\hline $16 \mathrm{~h} 30$ & Arrival at Painted lake \\
\hline $17 \mathrm{~h} 00$ & Arrival at the Canaleta viewpoint \\
\hline $17 \mathrm{~h} 30$ & Departure to the Mandur camp \\
\hline $18 \mathrm{~h} 30$ & Arrival at the Mandur camp \\
\hline $19 \mathrm{~h} 00$ & Dinner \\
\hline $20 \mathrm{~h} 00$ & Astrophotography (optional) \\
\hline 00h00 & Rest \\
\hline & DAY 2 \\
\hline $06 h 00$ & Equipment arrangement \\
\hline 07h00 & Breakfast \\
\hline $07 \mathrm{~h} 30$ & Lifting of the camp \\
\hline $08 \mathrm{~h} 00$ & Departure to the Bocatoma \\
\hline $13 \mathrm{~h} 00$ & Arrival at the Bocatoma and rest \\
\hline $14 \mathrm{~h} 00$ & Departure to Riobamba \\
\hline $15 \mathrm{~h} 30$ & Arrival to Riobamba \\
\hline
\end{tabular}

Alternative 2: Altar volcano summit

\begin{tabular}{|c|c|}
\hline \multicolumn{2}{|c|}{ DAY 1} \\
\hline Time & Activities description \\
\hline 06h00 & Departure from Riobamba (Vasija roundabout) \\
\hline $07 \mathrm{~h} 30$ & Arrival at the Bocatoma \\
\hline $08 \mathrm{~h} 00$ & Start of the route \\
\hline 09h30 & Padguazo forest arrival and breakfast \\
\hline $10 \mathrm{~h} 00$ & Departure to base camp \\
\hline $11 \mathrm{~h} 30$ & Arrival to base camp and rest \\
\hline $12 \mathrm{~h} 00$ & Arrival at the gates of the Altar \\
\hline $13 \mathrm{~h} 00$ & Arrival at Valley viewpoint \\
\hline $15 \mathrm{~h} 00$ & Arrival at the Mandur Lake \\
\hline $15 \mathrm{~h} 30$ & Arrival at the Italian camp, set up a tent and lunch \\
\hline $16 \mathrm{~h} 30$ & Glacier school departure and equipment review \\
\hline $19 \mathrm{~h} 00$ & Arrival at the Italian camp and dinner \\
\hline $20 \mathrm{~h} 00$ & Rest \\
\hline \multicolumn{2}{|r|}{ DAY 2} \\
\hline $23 \mathrm{~h} 00$ & Departure to the Bishop's summit attempt \\
\hline 07h00 & Arrival at the Bishop's summit \\
\hline $07 \mathrm{~h} 30$ & Departure to the Italian camp \\
\hline $11 \mathrm{~h} 30$ & Arrival to the Italian camp \\
\hline $11 \mathrm{~h} 30$ & Rest and lunch \\
\hline $12 \mathrm{~h} 30$ & Lifting of the camp \\
\hline $13 \mathrm{~h} 00$ & Departure to Bocatoma \\
\hline $17 \mathrm{~h} 00$ & Arrival at the Bocatoma \\
\hline $17 \mathrm{~h} 00$ & Rest \\
\hline $17 \mathrm{~h} 30$ & Departure to Riobamba \\
\hline $19 h 00$ & Arrival to Riobamba \\
\hline
\end{tabular}

Figure 8. Itinerary of the route.

\section{Discussion}

The PA are essential for the conservation and management of biodiversity and ecosystems [43]. In Ecuador, the PA are important sites for conservation and serve a wide variety of uses [33]. The Sangay National Park (PNS) is one of the best preserved PA of Ecuador [44] with a wide ecosystem [45] and faunistic diversity [46-48]. For the Ecuadorian Ministry of Environment, one of the principles of PA is to promote sustainable tourism, which involves the management, zoning, and establishment of strategic alliances with stakeholders [40]. Through this great biodiversity and landscapes, the lack of tourist routes would be a big problem to consolidate a unique experience in this area. So, the route mapping is a useful but little-used technique in visitor research [36]. In relation to the above-mentioned, this study showed new route alternatives with a thorough network analysis in GIS for tourists and locals visiting the AV.

In addition, they are potential areas for the realization of leisure and recreation activities in contact with nature [49]. The tourism use of these areas should be not only an instrument for the economic sustainability and well-being of surrounding populations, but also an object for their proper management [50]. The environment of PA is the raw material 
of tourist activity; it is imperative to find a balance between the use and protection of natural attributes, so that tourist attractions are maintained over time [51]. Therefore, a more adapted stewardship to increase the accessibility of the landscape could bring benefits by mobilizing more people near the tourist attractions [34].

The PNS has no populations immediately close; however, it is considered a tourist center for immediate populations such as Riobamba [52]. In the case of Riobamba Canton, it is surrounded by majestic landscapes and mountains; its different parishes have natural and cultural richness; one of the best-figure direct accesses to "El Altar" and its lake complex is by the parish "Santiago de Quimiag" [37]. In brief, "Capac Urco" has an interesting trekking trail: ecosystems along the route vary from tropical forests to glaciers [53]. At the starting point of the hike, the landscape seems a bit tropical, but at higher altitude, the landscape gradually transforms into pastures and herbs of moor, which has an incredible ability to store water through its unique vegetation, and its ecological and geological qualities. In addition, the weather is very unpredictable, so it is necessary to be ready for rain, and the mountains are often covered with thick clouds and fog. The study route is known as the "Inguisay-Las Puertas, Bocatoma" sector, which requires long walks through self-guided trails to the camping area; lakes can be visited in journeys of 1 to 3 days according to the interest of the visitor.

In this context, leisure is seen as a subjective experience, freely chosen, satisfying and of wide social scope [54-61]. As it happens with other manifestations of leisure, experiences that involve contact with nature bring a number of physical and mental benefits, such as perceived well-being, stress reduction, and physical and mental restoration $[59,62,63]$. However, tourist satisfaction is also achieved through a second way: emotional connections to the destination during the travel experience [64]. A positive emotional connection is based on a complex combination of negative and positive emotional interactions with attractions, facilities, and services during the travel [65].

In this way, the protection and management of a natural environment is an issue of interest and responsibility for agents involved in the tourist phenomenon and calls for an ethical stance of these agents in host communities and in visited environments [66]. The conditioning of these natural areas can promote the tourism and ecotourism activities; thus it contributes to improving the socio-economic development of the local population and promotes respect for nature in the destination [49]. Regarding the cleanliness and accessibility of the parks, there is a disjunctive; on the one hand, visitors seem to want and value a direct relationship with non-disturbed nature, in a space of intimacy with their close group; and on the other, there is a desire to improve accessibility and services [67]. Therefore, it is necessary to strengthen and maintain factors that enhance the level of tourist satisfaction, such as the diversification of tourist attractions and the viewing time, aspects that will make the perceived value of the trip exceed expectations within the "El Altar" route. The main effect of tourism and development of a community is the presence of a group of commoners, who are native tour guides trained in topics related to the improvement in the provision of tourist services.

On the other hand, the implementation of Geographic Information Systems (GIS) has enabled regional planning, as well as the organization and management of geographical space [68]. In tourist area, the importance of GIS resides in the management that can be given to geographical information, making it possible to represent the territories [69]. It has a significant contribution in planning and decision-making in order to strengthen the tourism within a specific territory. Indeed, itineraries are excellent options to promote the discovery of the environment and heritage [70,71]. In the case of the "Inguisay-Las Puertas" route, it was drawn up through georeferenced points.

\section{Conclusions}

According to the problems and objectives of the study, 19 points of interest were initially identified in the study area. The importance and characteristics of these sites made it possible to present two tourist route designs as alternatives for visiting the Altar 
Volcano in Sangay National Park. The first alternative allows visiting and/or observing 16 sites of interest, while the second alternative allows visiting and/or observing 15 points. These alternatives respond to the problems identified in the current tourism offer of Sangay National Park. The number of days required has been shortened to two; in addition, it can be hiked by hikers with little experience in mountain routes and points have been established to observe greater biodiversity and representative physical elements of the Andean zone.

For the selection of points of interest in the construction of alternative routes, aspects such as safety, scenic beauty, biodiversity, distances, and the time required to travel between attractions and tourist facilities were considered. These will generate confidence and a high level of visitor satisfaction during tourism activities. The itineraries will guarantee the tourist's enjoyment through a variety of activities. Thus, the activities include trekking, camping, and observation of lakes and peaks. It is important to note that the points of interest (SL, SIL, GL, MW, CV, YL, BL) were selected as viewpoints because they allow the visitor to enjoy in all their splendor representative landscapes of the Andean zone such as lakes, valleys, and peaks. This does not preclude access to them, as long as the difficulty of access and its restrictions are considered. The results obtained provide managers and administrators with a tourism management tool to increase the number of visitors without altering the level of satisfaction and boost the economy of local populations.

The main limitation identified in the study was the difficulty in carrying out field work due to the COVID-19 pandemic situation. At the same time, once in the field, this initial limitation facilitated the evaluative work since access to visitors was restricted. It is recommended to continue with the research processes in the study area with a focus on the identification of new points of tourist interest, with the objective of establishing alternative routes and itineraries with a greater number of days, which can link the results of this study. Other fundamental topic for future research is the evaluation of the level of satisfaction and possible environmental impacts on the fragile ecosystems of the area.

Author Contributions: Conception of the idea presented, A.V.G.M., D.D.C.V., and C.R.C.V.; conceptualization, A.V.G.M., D.D.C.V., C.R.C.V. and P.E.T.G.; methodology, A.V.G.M., J.F.E.P., C.R.C.V. and P.E.T.G.; software, J.F.E.P., P.E.T.G. and G.M.P.V.; writing —original draft preparation, A.V.G.M., D.D.C.V., G.M.P.V. and C.M.-R.; visualization, A.V.G.M., J.F.E.P., P.E.T.G. and G.M.P.V.; writing-review and editing, A.V.G.M., D.D.C.V. and C.M.-R.; supervision, A.V.G.M., D.D.C.V. and C.M.-R.; project administration, D.D.C.V. All authors have read and agreed to the published version of the manuscript.

Funding: This work was supported by the project "IDIPI-222-RETOUR—PRODUCTOS TURISTICOS SUSTENTABLES COMO ESTRATEGIA PARA EL DESARROLLO ECONOMICO DE LAS PARROQUIAS RURALES DEL CANTON RIOBAMBA, PROVINCIA DE CHIMBORAZO," funded by the Escuela Superior Politécnica de Chimborazo through the Research Institute (IDI-ESPOCH) and by the Transilvania University of Brasov, Romania.

Data Availability Statement: All the data generated and analyzed during this study are included in this published article.

Acknowledgments: This study is a part of the Sustainable Tourist Products Design Research Project from the Escuela Superior Politécnica de Chimborazo (RETOUR-ESPOCH). The research leading to these results has received logistical and financial support from the ESPOCH through the Research Institute (IDI-ESPOCH) and Transilvania University of Brasov, through the Faculty of Silviculture and Forest Engineering, Department of Forest Engineering, Forest Management Planning and Ter-restrial Measurement. The authors would also like to make a special mention of Stelian Alexandru Borz for their valuable support in checking the draft manuscript. Finally, we would like to thank to local people from Quimiag parish for sharing us their knowledge in the field trip and provide us particular information about the route.

Conflicts of Interest: The authors declare no conflict of interest. 


\section{References}

1. Orgaz, F.; Moral, S. El Turismo Como Motor Potencial Para El Desarrollo Económico de Zonas Fronterizas En Vías de Desarrollo. Un Estudio de Caso. El Periplo Sustentable 2016, 31, 1-17.

2. Zadeh, R.H.; Kiliç, H. Tourism Competitiveness and Tourism Sector Performance: Empirical Insights from New Data. J. Hosp. Tour. Manag. 2021, 46, 73-82. [CrossRef]

3. Rahman, M.A.; Hoque, N.; Alif, S.; Salehin, M.; Shariful, S.M.S.; Banik, B.; Sharif, A.; Nazim, N.B.; Sultana, F.; Cross, W. Factors Associated with Psychological Distress, Fear and Coping Strategies during the COVID-19 Pandemic in Australia. Glob. Health 2020, 16, 1-15. [CrossRef] [PubMed]

4. UNWTO Impact of COVID-19 on Global Tourism Made Clear as UNWTO Counts the Cost of Standstill. Available online: https: //www.unwto.org/news/impact-of-covid-19-on-global-tourism-made-clear-as-unwto-counts-the-cost-of-standstill (accessed on 20 July 2021).

5. UNWTO. Worst Year in Tourism History with 1 Billion Fewer International Arrivals. 2020. Available online: https://www.unwto. org/taxonomy/term/347 (accessed on 2 July 2021).

6. Gavilanes, A.V.; Castillo, D.D.; Esparza, J.F. Current Situation of Tourism in Ecuador: Challenges and Opportunities. Green World J. 2020, 3, 1-11.

7. Kiper, T. Role of ecotourism in sustainable development. In Advances in Landscape Architecture; Murat Özyavuz: Rijeka, Croatia, 2013; pp. 773-802. ISBN 978-953-51-5381-8.

8. UNWTO. Ecotourism and Protected Areas. Available online: https://www.unwto.org/sustainable-development/ecotourismand-protected-areas (accessed on 24 July 2021).

9. Forje, G.W.; Tchamba, M.N.; Eno-Nku, M. Determinants of Ecotourism Development in and around Protected Areas: The Case of Campo Ma'an National Park in Cameroon. Sci. Afr. 2021, 11, 1-7. [CrossRef]

10. Mestanza-Ramón, C.; Henkanaththegedara, S.M.; Vásconez Duchicela, P.; Vargas Tierras, Y.; Sánchez Capa, M.; Constante Mejía, D.; Jimenez Gutierrez, M.; Charco Guamán, M.; Mestanza Ramón, P. In-Situ and Ex-Situ Biodiversity Conservation in Ecuador: A Review of Policies, Actions and Challenges. Diversity 2020, 12, 315. [CrossRef]

11. Ministerio de Turismo del Ecuador (MINTUR). Plan Estratégico Institucional 2019-2021; Ministerio de turismo del Ecuador: Quito, Ecuador, 2019; pp. 1-112.

12. Ministerio de Turismo del Ecuador (MINTUR). Levantamiento de Información Sobre El Comportamiento Del Turismo a Nivel Nacional Dada La Nueva Normalidad Generada Por La Afectación Del Virus COVID-19; Ministerio de turismo del Ecuador: Quito, Ecuador, 2020; pp. 1-52.

13. Bayih, B.E.; Singh, A. Modeling Domestic Tourism: Motivations, Satisfaction and Tourist Behavioral Intentions. Heliyon 2020, 6 , 1-17. [CrossRef] [PubMed]

14. Li, T.T.; Liu, F.; Soutar, G.N. Experiences, Post-Trip Destination Image, Satisfaction and Loyalty: A Study in an Ecotourism Context. J. Destin. Mark. Manag. 2021, 19, 1-10. [CrossRef]

15. Moreno, S.; Celis, D.; Aguiar, T. Análisis de La Satisfacción Del Turista de Paquetes Turísticos Respecto a Las Actividades de Ocio En El Destino: El Caso de República Dominicana. Cuad. De Tur. 2002, 9, 67-84.

16. Pérez Aramburú, E. Estudio de Satisfacción de Turistas Nacionales y Extranjeros. Notas En Tur. Econ. 2010, 1, 32-48.

17. Morillo, M.C. Turismo y Producto Turístico. Evolución, Conceptos, Componentes y Clasificación. Visión Gerenc. 2011, 1, 135-158.

18. Shaykh-Baygloo, R. Foreign Tourists' Experience: The Tri-Partite Relationships among Sense of Place toward Destination City, Tourism Attractions and Tourists' Overall Satisfaction-Evidence from Shiraz, Iran. J. Destin. Mark. Manag. 2021, 19, 1-16. [CrossRef]

19. Díaz, B. El Diseño de Productos y Servicios Turísticos; Síntesis: Madrid, Spain, 2015; ISBN 978-84-9077-122-8.

20. Gómez, G. Procedimiento Metodológico de Diseño de Productos Turísticos Para Facilitar Nuevos Emprendimientos. RETOS Rev. De Cienc. De La Adm. Econ. 2014, 4, 157-172. [CrossRef]

21. Machado, E.L.; Hernández, Y. Procedimiento Para El Diseño de Un Producto Turístico Integrado En Cuba. Teoría Prax. 2007, 4, 161-174. [CrossRef]

22. Mise, S. The Role of Spatial Models in Tourism Planning; Springer: Reggio Calabria, Italy, 2018; pp. 105-112.

23. Yepes, V. Los Itinerarios Temáticos Como Elementos Diferenciadores Del Producto Turístico Global. Universidad Politécnica de Valencia. In Proceedings of the Actas del V Congreso Internacional de Caminería Hispánica, Valencia, Spain, 17-22 June 2016; pp. 1359-1372.

24. Sariego, I.; García, L. La Ruta Turística de Carlos V: Los Primeros Pasos En La Creación Del Producto. Int. J. Sci. Manag. Tour. 2016, 2, 439-466.

25. Lourens, M. Route Tourism: A Roadmap for Successful Destinations and Local Economic Development. Dev. S. Afr. 2007, 24, 475-490. [CrossRef]

26. Martos Molina, M. Las Rutas Culturales En El Desarrollo Territorial. Estudio de Casos y Propuestas Para El Camino Real e Intercontinental; Universidad Internacional de Andalucía: Sevilla, Spain, 2014; ISBN 978-84-7993-252-7.

27. Ministerio de Turismo del Ecuador (MINTUR). Manual de Generación de Rutas e Itinerarios Turísticos; Ministerio de Turismo del Ecuador: Quito, Ecuador, 2019; pp. 1-18.

28. Rodríguez, M. Diseño de Una Ruta Turística de Interpretación Cultural Para La Promoción y El Desarrollo Local de La Etnia Aborigen Warao En El Estado Delta Amacuro, Venezuela. Master's Thesis, Universidad de la Habana, La Habana, Cuba, 2010. 
29. Hernández, J. Los Caminos Del Patrimonio. Rutas Turísticas e Itinerarios Culturales. Pasos. Rev. De Tur. Patrim. Cult. 2011, 9, 225-236. [CrossRef]

30. Vu, H.Q.; Li, G.; Law, R. Discovering Implicit Activity Preferences in Travel Itineraries by Topic Modeling. Tour. Manag. 2019, 75, 435-446. [CrossRef]

31. Alcântara da Silva, A.; Morabito, R.; Pureza, V. Optimization Approaches to Support the Planning and Analysis of Travel Itineraries. Expert Syst. Appl. 2018, 112, 321-330. [CrossRef]

32. Gaudru, H. Volcano tourism-Central and South American examples. In Volcano and Geothermal Tourism; Routledge: Londres, Inglaterra, 2010; pp. 201-2014. ISBN 978-1-84977-518-2.

33. Castillo, D.D.; Chávez, C.R.; Marcu, M.V.; Gavilanes, A.V. The Use of Cultural Ecosystem Services: A Comparison BetweenlLocals and Tourists in the Chimborazo Natural Reserve. Bull. Transilv. Univ. Bras. 2020, 13, 1-18. [CrossRef]

34. Castillo, D.D.; Gavilanes, A.V.; Ricaurte, C.B.; Chávez, C.R.; Marcu, M.V.; Borz, S.A. Perception and Use of Cultural Ecosystem Services among the Andean Communities of Chimborazo Reserve. Environ. Eng. Manag. J. 2019, 18, 2705-2718. [CrossRef]

35. Carrión, P.; Borja, C.; Herrera, G.; Morante, F.; Jaya, M.; Maldonado, A.; Paz, N.; Berrezueta, E. Geosites and Geotourism in the Local Development of Communities of the Andes Mountains. A Case Study. Sustainability 2021, 13, 4624. [CrossRef]

36. Castillo, D.D.; Gavilanes, A.V.; Chávez, C.R.; Benalcázar, P.; Mestanza-Ramón, C. Design of Nature Tourism Route in Chimborazo Wildlife Reserve, Ecuador. Int. J. Environ. Res. Public Health 2021, 18, 5293. [CrossRef] [PubMed]

37. Gobierno Autónomo Descentralizado Municipal de Riobamba. Plan de Desarrollo y Ordenamiento Territorial Del Cantón Riobamba; Gobierno Autónomo Descentralizado Municipal de Riobamba: Riobamba, Ecuador, 2019; pp. 1-290.

38. Gobierno Autónomo Descentralizado Municipal de Riobamba El Altar. Available online: https://riobamba.com.ec/es-ec/ chimborazo/riobamba/volcanes/altar-adc5c8c8e (accessed on 20 July 2021).

39. Gobierno Autónomo Descentralizado Parroquial de Quimiag. Plan de Desarrollo y Ordenamiento Territorial de La Parroquia Quimiag; Gobierno Autónomo Descentralizado Parroquial de Quimiag: Quimiag, Ecuador, 2015; pp. 1-177.

40. Instituto Geográfico Militar del Ecuador (IGM). Caspas de Información Geográfica Del IGM (Codificación UTF-8). Available online: http:/ / www.geoportaligm.gob.ec/portal/index.php/descargas/cartografia-de-libre-acceso/registro/ (accessed on 27 July 2021).

41. Google Maps Tourist Attractions Coordinates and Tourist Infrastructure. Available online: https://www.google.com.ec/maps (accessed on 28 July 2021).

42. EarthExplorer Digital Model of Elevation and Landsat Layers, Band 2, 3, 4. Available online: https://earthexplorer.usgs.gov / (accessed on 27 July 2021).

43. Fontaine, G.; Narváez, I. Problemas de la gobernanza ambiental en el Ecuador. In Yasuní en el Siglo XXI. El Estado Ecuatoriano y la Conservación de la Amazonia; Abya-Yala: Quito, Ecuador, 2007; pp. 13-31. ISBN 978-2-8218-4411-7.

44. Batallas, D.; Brito, J. Nueva Especie de Rana Del Género Pristimantis Del Grupo Lacrimosus (Amphibia: Craugastoridae) Del Parque Nacional Sangay, Ecuador. Papéis Avulsos Zool. 2014, 54, 51-62. [CrossRef]

45. Ministerio del Ambiente del Ecuador (MAE). Proyecto: Sistema Nacional de Control Forestal; Ministerio del Ambiente del Ecuador: Quito, Ecuador, 2013; pp. 1-60.

46. Albuja, L. Diagnóstico Faunśtico Para La Actualización Del Plan de Manejo Del Parque Nacional Sangay; Plan Maestro para la Protección de la Biodiversidad Mediante el fortalecimiento del Sistema Nacional de Areas Protegidas: Quito, Ecuador, 1996.

47. Guevara, E.A.; Santander, T.; Guevara, J.; Gualotuña, R.; Ortiz, V. Birds, Lower Sangay National Park, Morona-Santiago, Ecuador. Check List 2010, 6, 319-325. [CrossRef]

48. Brito, J.; Almendáriz, A. Anfibios y Reptiles Del Parque Nacional Sangay. Patrimonio Natural de La Humanidad, Ecuador; Instituto de Ciencias Biológicas, Escuela Politécnica Nacional: Quito, Ecuador, 2013; pp. 1-9.

49. Orgaz, F. Acondicionamiento de las Áreas Protegidas para el Desarrollo de Actividades de Ocio y Recreación. Econpapers 2013, 6, $1-3$.

50. Reck, G.; Martínez, P. Áreas protegidas: ¿turismo para la conservación o conservación para el turismo? Polémika 2010, 2, 86-95.

51. Rudzewicz, L.; Lanzer, R.M. Ecoturismo y Conservación de Los Ecosistemas: Reservas Particulares de Patrimonio Natural En Brasil. Estud. Perspect. Tur. 2008, 17, 226-249.

52. Delgado, M.; Martínez-Fresneda, M.; Villarruel, A. Valoración Económica Del Servicio Limnológico de La Laguna MagdalenaAtillo, Riobamba-Ecuador. Enfoque UTE 2019, 10, 1-16. [CrossRef]

53. Kutzinski, V. Alexander von Humboldt's Transatlantic Personae; Taylor \& Francis: Abingdon, UK, 2012.

54. Cuenca, M. Ocio Humanista. Dimensiones y Manifestaciones Actuales Del Ocio; Universidad de Deusto: Bilbo, Spain, 2000.

55. Cuenca, M. Aproximación Multidisciplinar a Los Estudios de Ocio; Universidad de Deusto, Servicio de Publicaciones = Argitalpen Zerbitzua: Bilbo, Spain, 2006; ISBN 978-84-9830-458-9.

56. Cuenca, M. Ocio Valioso; Universidad de Deusto: Bilbo, Spain, 2014; ISBN 978-84-15759-48-5.

57. Henderson, K.A.; Presley, J.; Bialeschki, M.D. Theory in Recreation and Leisure Research: Reflections from the Editors. Leis. Sci. 2004, 26, 411-425. [CrossRef]

58. Iso-Ahola, D. Social Psychological Perspectives on Leisure and Recreation. Am. J. Occup. Ther. 1980, $34,750$.

59. Kaplan, R.; Kaplan, S. The Experience of Nature: A Psychological Perspective; Cambridge University Press: Cambridge, UK, 1989.

60. Lee, Y.; Dattilo, J.; Howard, D. The Complex and Dynamic Nature of Leisure Experience. J. Leis. Res. 1994, 26, 195-211. [CrossRef] 
61. Tinsley, H.E.; Tinsley, D.J. A Theory of the Attributes, Benefits, and Causes of Leisure Experience. Leis. Sci. 1986, 8, 1-45. [CrossRef]

62. Marrero, R.J.; Carballeira, M. Contact with Nature and Personal Well-Being. Psyecology 2010, 1, 371-381. [CrossRef]

63. Ulrich, R.S.; Simons, R.F.; Losito, B.D.; Fiorito, E.; Miles, M.A.; Zelson, M. Stress Recovery during Exposure to Natural and Urban Environments. J. Environ. Psychol. 1991, 11, 201-230. [CrossRef]

64. Bosque, I.R.; Martín, H.S. Tourist Satisfaction a Cognitive-Affective Model. Ann. Tour. Res. 2008, 35, 551-573. [CrossRef]

65. Okello, M.M.; Yerian, S. Tourist Satisfaction in Relation to Attractions and Implications for Conservation in the Protected Areas of the Northern Circuit, Tanzania. J. Sustain. Tour. 2009, 17, 605-625. [CrossRef]

66. Boullón, R. Ecoturismo Sistemas Naturales y Urbano; Ediciones Turísticas: Buenos Aires, Argentina, 2000; Volume 2, ISBN 978-9879473-23-8.

67. Ried, A.; Ayala, C.; Carmody, S.; Le Bon, A.; Santos, R.; Smart, I. Leisure Experience in Protected Areas as a Source of Sense of Place: What Do Visitors Say? Psyecology 2019, 10, 1-30. [CrossRef]

68. Niño, S.G.; Danna, J.P. Los Sistemas de Información Geográfica (SIG) En Turismo Como Herramienta de Desarrollo y Planificación Territorial En Las Regiones Periféricas. Cid. Comunidades E Territ. 2016, 32, 18-39. [CrossRef]

69. López, J.; Larios, C.; Campillo, L. Aplicación de Un SIG Para Ubicar e Identificar Las Zonas de Interés Turístico y La Infraestructura En La Reserva Ecológica Cascadas de Reforma, Balancán, Tabasco. Sem. Divulg. Video Científico 2008, 1, $173-178$.

70. Arizala-Guachamín, Y.N.; Chilán-Toala, P.M.; González-Suárez, N.R.; Parrales-Vásquez, M.M.; Vera-Andrade, E.A. Realización de Un Sendero Como Herramienta de Interpretación Ambiental Para Promover La Protección y Conservación Del Bosque Seco de Loretoen El Cantón Esmeraldas. Gestión Ambient. 2018, 16, 27-32.

71. Rodríguez, J.L. Red de Senderos, Una Fuente de Turismo. Tándem Didáctica Educ. Física 2017, 56, 42-45. 